\title{
Article
}

\section{The poet, the newspaper editor, and working-class local literary culture in Victorian Blackburn}

\author{
Hobbs, Andrew \\ Available at http://clok.uclan.ac.uk/28508/ \\ Hobbs, Andrew ORCID: 0000-0001-5943-475X (2019) The poet, the \\ newspaper editor, and working-class local literary culture in Victorian \\ Blackburn. Transactions of the Historic Society of Lancashire and Cheshire, \\ 168. ISSN 0140-332X
}

It is advisable to refer to the publisher's version if you intend to cite from the work. http://dx.doi.org/10.3828/transactions.168.8

For more information about UCLan's research in this area go to http://www.uclan.ac.uk/researchgroups/ and search for < name of research Group>.

For information about Research generally at UCLan please go to http://www.uclan.ac.uk/research/

All outputs in CLoK are protected by Intellectual Property Rights law, including Copyright law. Copyright, IPR and Moral Rights for the works on this site are retained by the individual authors and/or other copyright owners. Terms and conditions for use of this material are defined in the policies page.

\section{CLoK}

Central Lancashire online Knowledge www.clok.uclan.ac.uk

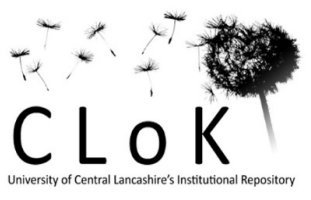




\title{
The poet, the newspaper editor, and working-class local literary culture in Victorian Blackburn
}

\section{Andrew Hobbs}

\begin{abstract}
This article offers the first detailed account of a local working-class 'verse culture', and examines the factors which created it, taking as a case study the town of Blackburn, Lancashire, in the second half of the nineteenth century. It uses content analysis, bibliography, memoir, newspaper archives, a poet's cuttings book and a local historian's manuscript book to argue that reading, writing and performing poetry was an important part of working-class Victorian culture, that culture was produced far from the metropolitan centre (whilst heavily influenced by a poetic canon), and that local newspapers played an important role in producing such local cultures. Blackburn had a typical working-class cultural infrastructure, of mutual improvement, clubs and associations, its pride in local and regional traditions and its thriving newspapers. From this, two exceptional individuals helped to create an extraordinary poetic culture, the town's leading poet William Billington, and the editor of the Blackburn Times, William Abram.
\end{abstract}


About ten o'clock one evening in the early 1870s, some 20 members of the Blackburn Literary Club walked from their club rooms in Cort Street to the Nag's Head in Northgate, after an evening of recitation and literary criticism. William Abram, a founder of the club, later recalled the reaction of the Nag's Head landlord, William Billington, a noted poet himself:

Billington was delighted to receive us, and we were accommodated in his largest room, which was closed for the night to other customers. Then followed what Professor Wilson might have described as one of his 'Noctes Ambrosoeanoe.' Among the party were poets, chief of them the host himself; excellent elocutionists, singers, journalists, and literary critics. Each had some contribution to make to the entertainment. Billington was in his natural element. Like 'Tam o' Shanter,' among his cronies in the inn, William 'was glorious, o'er all the ills of life victorious.' Recitation, criticism, song, discussion, comical story, and bandied 'chaff' succeeded each other.

The soiree came to an abrupt halt at $1.15 \mathrm{am}$ when a passing constable reported them for drinking after hours. ${ }^{1}$

This pleasant literary evening contains the essence of Blackburn's unusual Victorian working-class literary culture, in its flavour and in the reasons for its dynamism. Blackburn's working-class residents had an infrastructure, of clubs and other 'associational culture'; an ethos of mutual improvement; pubs and rooms in which to chat about Chaucer, a pride in local and regional culture, symbolised by the reference to 'Tam O'Shanter', a poem celebrating conviviality written in Lowland Scots and standard English by Robert Burns (a major influence on Lancashire dialect writers), and local newspapers staffed by literary types. The allusion to the 'Noctes Ambrosianae', a series of imaginary drink-fuelled literary discussions in Blackwood's Magazine, and the mention of literary criticism, suggest some self-awareness if not self-importance, and a conscious display of 'cultural

\footnotetext{
${ }^{1}$ W. Abram, Blackburn Characters of a Past Generation (Blackburn, 1894), 229-230. Thanks to Mary Painter (Community History Librarian, Blackburn Central Library), to the two anonymous referees and to the North West Long Nineteenth Century Seminar and Blackburn Local History Society for comments on earlier versions.
} 
capital'. Everyone took part, demonstrating the participatory, culturally democratic atmosphere, while the presence of elocutionists and singers mixed performance and oral culture with literature. ${ }^{2}$

Scores of other towns and cities had this same infrastructure, but two individuals made Blackburn different, the central character of this anecdote and the teller of the tale. The first was the pub landlord, William Billington (1827-84), a former mill worker and accomplished poet, who believed in education and the nurturing of literary talent; he mentored many younger writers, and made his pubs a home for those who thirsted after knowledge as much as beer. The second was the writer of the anecdote, William Alexander Abram (1835-94), who used his position as editor of the Blackburn Times to publish, encourage, review, critique, celebrate, subsidise and commemorate the town's would-be litterateurs. The outlook and talents of these two exceptional individuals brought together and promoted an unusually large and active network of working-class poets.
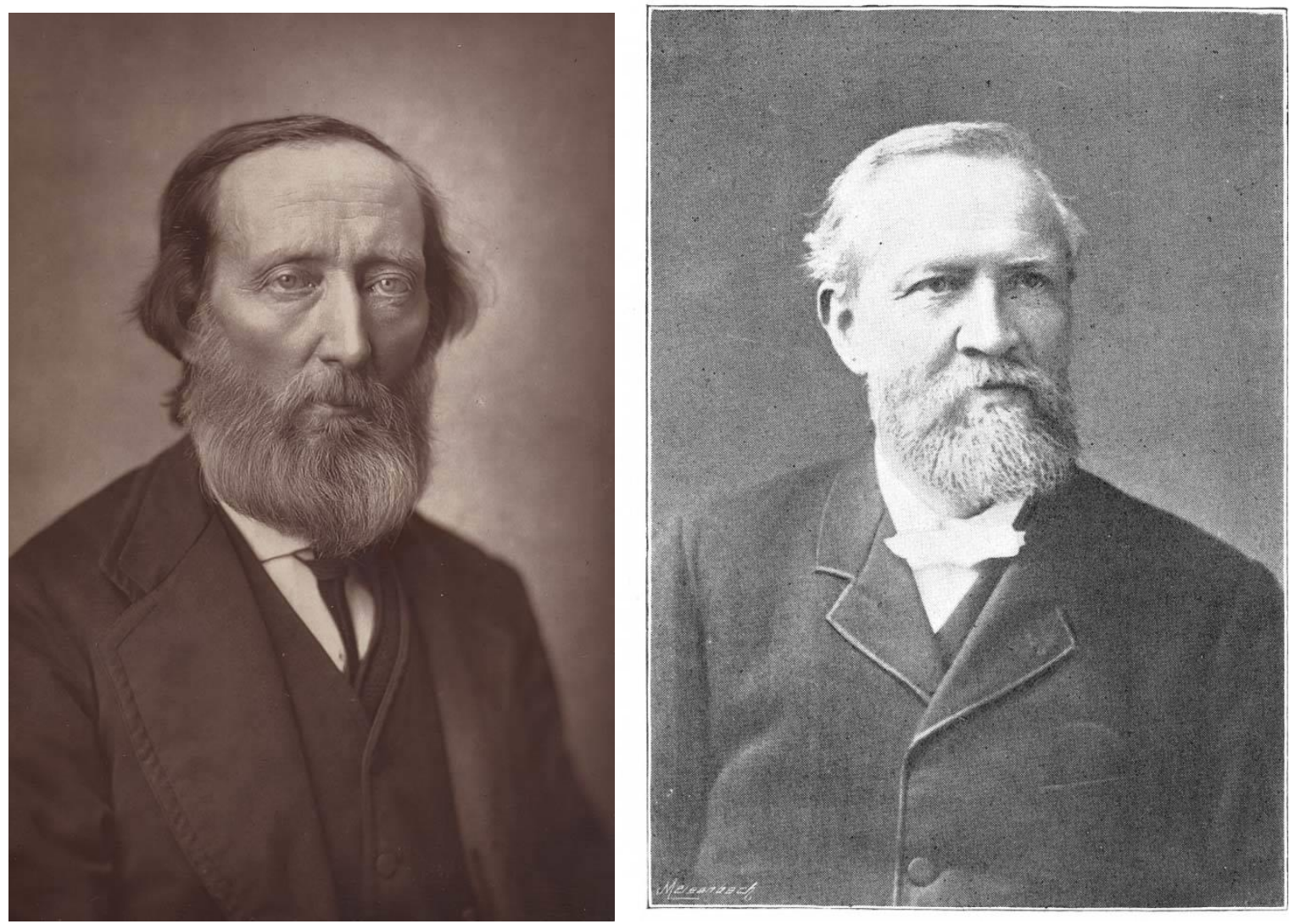

Figure 1. William Billington (left) and William Alexander Abram.

\footnotetext{
${ }^{2}$ An 'elocutionist' was a skilled performer of the spoken word, in dialect or Standard English, for example: 'Mr J. King's recitations in the Lancashire dialect proved that gentleman an elocutionist of no mean ability', Cheshire Observer 8 May 1897, p.5.
} 
This article offers the first detailed account of a local working-class 'verse culture', and examines the factors which created it. It uses content analysis, bibliography, memoir, newspaper archives, a poet's cuttings book and a local historian's manuscript book to argue that reading, writing and performing poetry was part of working-class life in this era, that a great deal of Victorian culture was produced far from the metropolitan centre, whilst heavily influenced by a poetic canon, and that local newspapers played an important role in producing such local cultures.

'Blackburn, it is safe to say, has produced more weavers of calico and of verse than any other town in the United Kingdom,' wrote John Walker, a former Blackburn journalist, introducing a volume of local poetry. ${ }^{3}$ Roughly a quarter of the poetry in a 1922 Lancashire Anthology came from Blackburn, demonstrating the town's disproportionate contribution to the county's literature. ${ }^{4}$ The largest centre in north-east Lancashire, its population grew from 76,549 in 1851 to 127,626 in $1901 .^{5}$ It was known for cotton weaving, and returned two MPs to Parliament, usually Conservative, during the nineteenth century. At least 20 newspapers came and went during that time, and for most of the century the town supported two weekly papers of opposing politics.

Blackburn's working-class verse culture was unusual, but not unique. Manchester, Newcastle, Dundee and Glasgow supported similar circles, and there are no doubt many more to be rediscovered.

Manchester's was one of the most famous, numbering more than 50 writers during the 1830s and 1840s, including many who achieved regional, if not national fame, and the prestige of volume publication. ${ }^{6}$ However, most of their work was published in the city's newspapers and magazines, and

\footnotetext{
${ }^{3}$ J. Walker, 'Introduction', in R. Rawcliffe and J. Rawcliffe Pebbles Fro' Ribbleside (Blackburn, 1891), 1.

${ }^{4}$ Twenty-one of 89 poems and nine of 35 poets are from Blackburn in M. Yates, A Lancashire Anthology (Liverpool, 1923).

5 'Blackburn: Total Population,' A Vision of Britain Through Time <http://www.visionofbritain.org.uk/unit/10341826/cube/TOT_POP>.

${ }^{6}$ D. Bark, 'Manchester and Early Victorian Literary Culture', Literature Compass 8:6 (2011), 404414; M. Vicinus, 'Literary Voices of an Industrial Town: Manchester, 1810-70', in H. J. Dyos and Michael Wolff (eds), The Victorian City: Images and Realities, vol. 2 (London, 1973), 742.
} 
in local papers across North-West England and further afield. They met at the Sun Inn in Manchester. ${ }^{7}$ As with most of these local literary cultures (Goodridge and Burke also identify groups in Sheffield and Nottingham), a significant proportion of the participants were working-class. ${ }^{8}$ Newcastle's bardic community was said to be so strong that poets 'flourished as common and prickly as brambles along the banks of the Tyne. ${ }^{9}$ Kirstie Blair describes the working-class verse culture of Dundee, with its literary societies and discussion groups from the 1840s onwards, encouraged by middle-class figures such as George Gilfillan, a Presbyterian minister, author and poet, and John Leng, publisher of the People's Journal, one of Scotland's most successful newspapers. ${ }^{10}$ In Glasgow there were circles of poets associated with the Glasgow Weekly Mail and the Penny Post.$^{11}$ Scholars of the eighteenth century such as Chandler and Crawford have studied middle-class local literary cultures in Norwich and Exeter and other towns and cities, but I have found no studies of working-class equivalents in that period, and certainly nothing as lively and multi-faceted as Blackburn. ${ }^{12}$ Common to all these local literary cultures is the importance of the local press.

\section{Billington, Abram and Blackburn's local poets}

\footnotetext{
${ }^{7}$ C. Sutton, 'Rogerson, John Bolton (1809-1859), poet', Oxford Dictionary of National Biography; this group is well represented in B.E. Maidment, The Poorhouse Fugitives: Self Taught Poets and Poetry in Victorian Britain (Manchester, 1992).

${ }^{8}$ J. Goodridge, 'Informal Notes on Groupings, Circles and Categories', in Database of British and Irish Labouring-Class Poets \& Poetry 1700-1900 (2019)

<https://www.academia.edu/23444877/A_Database_of_British_and_Irish_Labouringclass_Poets_1700-1900>.

${ }^{9}$ P. Gilchrist, 'Bard of Tyneside: Robert Gilchrist (1797-1844)' <http://www.academia.edu/782400/Bard_of_Tyneside_Robert_Gilchrist_1797-1844_>.

${ }^{10}$ K. Blair, “"A Very Poetical Town”: Newspaper Poetry and the Working-Class Poet in Victorian Dundee', Victorian Poetry 52:1 (2014), 89-109.

${ }^{11}$ J. Rosen, 'Class and Poetic Communities in the Works of Ellen Johnston, "The Factory Girl", Victorian Poetry 39:2 (2001), 207-28; E. Cohen and L. Fleming, 'Mirren's Autobiography: The Life and Poetry of Marion Bernstein (1846-1906)', Scottish Literary Review 2 (2010), 59-76.

${ }^{12}$ David Chandler, “"The Athens of England": Norwich as a Literary Center in the Late Eighteenth Century', Eighteenth-Century Studies 43:2 (2010), 171-192; J. Crawford, "Behindhand with Their Countrymen": Literary Culture and Economic Decline in Eighteenth-Century Exeter', EighteenthCentury Studies 51:4 (2018), 417-436.
} 
Blackburn's twentieth-century historian, George C. Miller, was probably right when he identified two decisive factors in the town's distinctive working-class literary culture: a succession of newspaper editors and publishers committed to publishing the work of local poets (I would single out Abram of the Blackburn Times), and 'the inspiration and leadership of that remarkable genius, William Billington' ${ }^{9}$ Their stories, intertwined with those of other key figures, give a flavour of the town's literary milieu.

Billington came to Blackburn from the village of Samlesbury at the age of 12 in 1839, and began to write poetry in the 1840s. As a teenager he met an older poet, Richard Dugdale (1790-1874), a selfeducated ex-soldier who became an engraver, and who called himself the 'Bard of Ribblesdale'. He claimed to have met a relative of Burns, of whom he was a great admirer. Dugdale befriended Billington, mentored him and introduced him to other local writers. ${ }^{14}$ These included Joseph Hodgson (1783-1856), a handloom weaver who published many of his own poems himself, as broadsheets, which he carried in his hat and hawked wherever he went. His poems included 'The Weaver's Complaint' (on the decline of hand-loom weaving), and 'Blackburn Election' from the 1830s, which begins:

These ten-pound electors can guzzle in beer,

And censure corruption, as if they were clear. ${ }^{15}$

Some of his verse was published in the Radical Blackburn Mail and the Tory Blackburn Standard. Hodgson had been librarian of the Mechanics' Institution (opened in 1844), and had his own library of 800 volumes. $^{16}$

\footnotetext{
${ }^{13}$ Blackburn Central Library (hereafter BCL), G. C. Miller, 'Blackburn's Brotherhood of Song: 14, James Walkden', typescript of Blackburn Times article, in 'Notes on Local History' (hereafter Miller typescript), vol. 11, 241. Billington's leadership is also highlighted by Michael Watson, 'William Billington: Cotton Operative, Teacher and Poet', Transactions of the Historic Society of Lancashire and Cheshire 134 (1985), 86.

${ }^{14}$ BCL, M.I. Watson, 'William Billington: The Blackburn Poet' (pamphlet, n.p., n.d.), 4.

${ }^{15}$ G. Hull, The Poets and Poetry of Blackburn (Blackburn, 1902), $25<\mathrm{http}: / /$ geraldmassey.org.uk/hull/b_blackburn_poets.htm>.

${ }^{16}$ Obituary, Blackburn Standard, reprinted in Lancaster Gazette, 16 February 1856.
} 
Other poets already active when Billington came to Blackburn were James Walkden (1825-1901), a Radical young compositor (typesetter) who worked for his Tory uncle of the same name, printing the Blackburn Standard, and John Baron (1823-80), a handloom weaver who later worked in a mill. The entwining of poetry and journalism can be seen in the joint publication by Walkden junior and Baron of a book of their verse, Flowers of Many Hues (1847), printed by Robert Wilson Smiles (1816-90). Smiles was the younger brother of Samuel Smiles of Self-Help fame, and had briefly edited the Liberal Blackburn Mercury (1843-46). Nowadays we might say that Billington and Baron became 'frenemies', poetic and political rivals, sometimes writing in praise of each other, at other times slinging mud (reminiscent of 'flyting', the ancient Scottish tradition of trading poetic insults). They were once both targets of the eccentric Hodgson, who hired two street-ballad singers to promote a lampoon entitled 'The Pigs in my yard', which began: 'There's Baron and Billington would be two bards'. Their retort in rhyme was addressed to 'J. Hodgson, the Porcine Poet'. ${ }^{17}$

The writer with the greatest fame at the time was John Critchley Prince (1808-66), who lived and worked in Blackburn sporadically, but had a significant influence on the town's writers, who venerated him greatly. Born in Wigan and a reed-maker by trade, he had early success with his volume Hours with the Muses (1840) and became leader of the Sun Inn group of Manchester poets, but lived in poverty. In Blackburn he socialised with local poets; once, in 1849, he borrowed a sovereign (one pound) from Dugdale. When he failed to pay it back Dugdale wrote a poem, 'The Sovereign', in which every stanza began with 'Prince' and ended with 'Sovereign'. Prince repaid him with a touching composition entitled 'Forgiveness'. ${ }^{18}$ When Prince returned to Blackburn in 1853-54 he got to know Billington, who was taken with Prince's stories of the Sun Inn, and later used that pub's nickname of 'Poet's Corner' to emulate the atmosphere of the Manchester inn in Blackburn. ${ }^{19}$

\footnotetext{
${ }^{17}$ BCL, Miller typescript vol. 1, 'Focus on yesterday: Poet's Corner', 194.

${ }^{18}$ G.C. Miller, Blackburn: The Evolution of a Cotton Town: A History of the Ancient Township of Blackburn in Lancashire, Written to Commemorate the Centenary of Its Incorporation in 1851 (Blackburn, 1952), 240.

${ }^{19}$ BCL, Miller typescript vol. 3, 'Poet's Corner' 413.
} 
Billington was largely self-taught, after learning to read at Sunday School. Whilst working as a weaver he joined the Mechanics' Institution, set up a 'Mutual Instruction Association', taught himself grammar and joined a lecture and debating society. As a young man he was notorious as an atheist, and began to have poems published in local papers in the 1850s, collecting them in his first volume, Sheen and Shade, in 1861, the publication sponsored by local solicitor and musician Thomas Clough, with editorial assistance from Abram. ${ }^{20}$ Billington wrote in Standard English and in Lancashire dialect, having great success during the Lancashire Cotton Famine (1861-64) with the dialect poem 'Th' Surat Weyver', about the poor-quality Indian thread that substituted for American cotton during the Civil War. In 1869 Billington took over the Nag's Head in Northgate, making it a focal point of literary culture and education, and in 1875 he moved to a beerhouse on the corner of Nab Lane and Bradshaw Street which he named 'Poet's Corner'. For the next ten years, until his death in 1884, it was an important centre of working-class literary and educational activity, including Sunday evening debates, whose subjects, advertised in the Blackburn Times, included 'Wordsworth v. Byron'. There were also lectures and poetry readings. ${ }^{21}$ His second volume, Lancashire Songs, Poems and Sketches, came out in 1883 .

Editors and journalists were an important part of Blackburn's literary culture. In the Victorian era, what we would nowadays call the editorial section of a newspaper, or newsroom, was often known as the 'literary department', and there was a great deal of overlap between literature and journalism. ${ }^{22}$ Indeed 'a substantial number of newspaper employees started out as newspaper poets'. ${ }^{23}$ Abram was Victorian Blackburn's most significant newspaper editor and patron of local poets; 'he loved Literature and taught others to love it'. He liked to read aloud the poetry of Tennyson, Wordsworth, Byron and Swinburne (but never Browning aloud), and the Elizabethan and Cavalier poets. ${ }^{24}$ The son

\footnotetext{
${ }^{20}$ Abram, Blackburn Characters, 120, 224.

${ }^{21}$ Watson, 'William Billington: Cotton Operative, Teacher and Poet', 82.

${ }^{22}$ L. Brake, Subjugated Knowledges: Journalism, Gender and Literature in the Nineteenth Century (Basingstoke, 1994).

${ }^{23}$ K. Blair, 'The Newspaper Press and the Victorian Working Class Poet', in J. Goodridge and B. Keegan (eds), A History of British Working Class Literature, (Cambridge, 2017), 268.

${ }^{24}$ E.W. Abram, preface, xxiii; anonymous memoir, xxxi, both in Abram, Blackburn Characters.
} 
of a nonconformist minister, he was born at Lydiate near Southport, attended a school for the sons of ministers at Silcoates near Wakefield as a contemporary of the journalist WT Stead, and moved to Tockholes near Blackburn as a teenager. He was apprenticed to Blackburn printer John Neville Haworth as a compositor, and continued his education at Blackburn Mechanics' Institution. He worked as a compositor in London for the scientific and medical publisher J.E. Adlard, before returning to Blackburn, where he edited the short-lived Blackburn News, published by Haworth in 1860 , before taking charge of the newly opened public library in the same year. ${ }^{25} \operatorname{In} 1863$, two years after the Manchester Literary Club was formed, Abram helped to found Blackburn Literary Club (he played the part of a barrister in the club's staging of the mock trial between Bardell and Pickwick from Dickens's Pickwick Papers) and co-edited the complete works of the Cavalier poet Robert Herrick (1591-1674) with Rev. Alexander B Grosart, minister of St George's Presbyterian Church of England, Blackburn. ${ }^{26}$ In 1867 he became editor of the Liberal Blackburn Times (whilst maintaining an interest in the free library for the rest of his life).

Abram edited the Blackburn Times for 20 years before resigning over Gladstone's Irish Home Rule policy, jumping ship to a new Conservative paper, the Blackburn Express, in 1887. The outrage among the town's Liberals at this change of allegiance was expressed in typical poetic form. Abram was keen to continue his encouragement of local poets in his new job, and published a poem from the unknown Mary Richardson, welcoming the town's new paper (Figure 2). Abram did not notice that the poem was an acrostic, the first letter of each line spelling out its message.

25 'Death of Mr WA Abram JP', Weekly Standard and Express, 5 May 1894, 5; 'Sudden death of Mr W A Abram, JP', Preston Herald, 5 May 1894, 2.

${ }^{26}$ Anonymous memoir in Abram, Blackburn Characters, li, lii.; Vicinus, 'Literary Voices', 752. 
Over a building in Blackburn town,

Under the noble church tower's shade,

Reared high in the air is the word Express,

Resting in gold on a broad facade.

Enter the doors, buy the bran-new sheet,

Newsy, piquante, sparkling, and bright;

Every day is the news of the world

Given at length ere the fall of night.

A sight to cause wonder-you panse, and see Different men at their separate posts;

Every " hand" at his duty works,

Each proud of the print which the town now boaste.

Drawn by the clatter the big press makes

In printing the sheets at an Express pace,

The mind is fllled with many thoughts

Of the wondrous skill of the human race!

Ringing the music of honour and peace, Ireland, the cause of the brave and the free,

Shall we not give our support to that Press, And defend it wherever its enemies be?

Now we are flghting for country and Queen, And home, and poor Ireland's wrongs to redress,

Shall not The Express, therefore, lead a staunch band, So that what we are wanting may soon come to pass?

Mary RICHARDson. 27

Figure 2. Acrostic poem mocking Abram, editor of the Blackburn Express, 27 September 1887.

The new paper carried little poetry after that. Another notable editor and literary patron was William

Hall Burnett (1840-1916), born to a poor agricultural family in Stokesley, in the North Riding of

Yorkshire. He came to Blackburn in 1887 as editor of the Blackburn Standard and took over as editor of the merged Blackburn Standard and Express when Abram retired in 1890.

After Billington's death in 1884, Blackburn remained a hotbed of verse, but the sense of a physical community, including poets meeting in pubs and verbal and literary sparring, declines. Yet the town's newspapers were still full of poetry, including a weekly poem, between a half and two-thirds of a broadsheet column long, in the Blackburn Times, by foundry worker John Thomas Baron (1856-1921) for more than 30 years. He wrote some 1,800 'Rhymes in the Dialect' for the Times, plus many other

${ }^{27}$ Blackburn Express, 27 Sept 1887. 
poems, some in standard English, some in dialect (the latter signed 'Jack o'Ann's'). Such pseudonyms, or initials, were typical, often giving little clue as to authorship. But of those whose gender can be identified, in an analysis of the Blackburn Standard (a year's worth of issues every 20 years, from 1840 to 1900 ), about one third were by women (this method is not entirely reliable as John T Baron sometimes used the pen-name 'Nora B', and Carlisle poet Mary Smith wrote election squibs as 'Burns Redivivus'). ${ }^{28}$ Some Blackburn women published volumes of poetry: Matilda Harrison's The Poet's Wreath (1890) and Margaret Munro ('Gilbert Gillespie') and Ellen Ling produced a combined volume, Poems by Two Friends, published in 1905 by Blackburn and District Authors' Society. The society also encouraged Blackburn's most famous woman writer, Ethel Carnie (1886-1962), 'the first British working-class woman to sustain a long and varied publishing career', nurtured in Blackburn's literary culture. ${ }^{29}$ She produced three volumes of poetry, Rhymes from the Factory (1907), Songs of a Factory Girl (1911) and Voices of Womanhood (1914). However, only five of the 55 writers discussed in George Hull's anthology, The Poets And Poetry Of Blackburn (1902), were women.

Billington and Abram crop up repeatedly in any account of Blackburn's Victorian poetry and poets. Billington absorbed the canons of national, regional and local poetry and poets; poetry changed his life, and he wanted to pass on this magic to others. He succeeded in doing this because he was gregarious, generous in his unpaid teaching, coaching and encouragement, active in all of Blackburn's literary initiatives, and turned his pub and beerhouse into literary venues. All of this was helped by the fact that he was a very talented self-taught writer, who became a role model for others. Blackburn's most significant newspapermen, Abram and Burnett, came from relatively humble backgrounds, and benefited from the working-class culture of mutual improvement. They were committed to education and the development of literary talent wherever they found it, especially among working-class writers. We know less about James Walkden, the publisher of the Tory Blackburn Standard, and its

\footnotetext{
${ }^{28}$ Hull, Poets and Poetry, 369; M. Smith, The Autobiography of Mary Smith, Schoolmistress and Nonconformist, a Fragment of a Life (Carlisle, 1892), 260.

${ }^{29}$ P.E Johnson, 'Finding Her Voice(s), The Development of a Working-Class Feminist Vision in Ethel Carnie's Poetry', Victorian Poetry 43:3 (2005), 297.
} 
succession of obscure editors, but Walkden too seemed to share a belief in publishing local workingclass writers (not least because it was good for business). The impact of Billington and Abram was enabled by four factors, found in many other towns and cities. These were an ethos of self-education and mutual improvement; a rich associational culture; local pride, and a vibrant local press. ${ }^{30}$

\section{Autodidacts and mutual improvement}

Many of the potted biographies in Hull's anthology proudly note that the poet was self-taught; Billington educated himself in the canon of British poetry as a teenager in his few leisure hours, and by the age of 26

had not only read and re-read Shelley, Bryon, Keats, and Burns through, until he could recite hundreds of lines of each of them, but was well-versed in the older poets, Chaucer, Spencer, Shakespeare, Milton, Dryden and Pope; and in the later works of Scott, Coleridge and Wordsworth. ${ }^{31}$

Public libraries and those provided by the co-operative movement were a boon to the autodidact. Fifty years later, Ethel Carnie (1886-1962) borrowed books from the co-operative lending library in Great Harwood (a small town outside Blackburn) as a child and half-timer in a mill..$^{32}$ There were informal mutual improvement groups, such as the one that Luke Slater Walmsley (b. 1841) joined in the 1850s

for the study of English grammar and belles-lettres. We met in the cottage of a member, with Poet Billington as teacher. Never shall I forget his opening lecture! Billington was a model teacher, and gave us a thorough grip of grammar and a passable knowledge of

\footnotetext{
${ }^{30}$ Blair has identified similar reasons for Dundee's comparable culture, highlighting the leadership of John Leng, the publisher of that city's most popular newspaper, the People's Journal: ("“A Very Poetical Town", 91-92). Chandler argues that Norwich's local literary culture in the last quarter of the eighteenth century was enabled by the leadership of nonconformist minister William Enfield (a former 'tutor in belles lettres' at Warrington Academy) and the editors of the local newspapers ("“The Athens of England"').

${ }^{31}$ Watson, 'William Billington: Cotton Operative, Teacher and Poet', 77; Abram, Blackburn Characters, 223-224.

${ }^{32}$ N. Wilson, 'Ethel Carnie Holdsworth: Genre, Serial Fiction and Popular Reading Patterns', in Goodridge and Keegan, 313.
} 
rhetoric, and led us on to an abiding love of the sweet pastures of English literature. I am under lasting gratitude to him. ${ }^{33}$

Such informal groups continued alongside the mechanics' institute, which opened in 1844 -- one mutual instruction society had its own rooms in Ainsworth St in 1852, and Billington turned his pub, and then his beerhouse, into informal night schools. ${ }^{34}$

The graduates of these various places of learning wore their learning on their sleeves, in their verse (particularly in tributes to other poets), in their conversations and even their arguments. Billington's first volume, Sheen and Shade, included sonnets to Chaucer, Spenser, Shakespeare, Milton, Pope, Thomson, Byron, Keats, Gerald Massey and Burns. Many Blackburn poets wrote about Burns, and about famous Lancashire poets such as 'Tim Bobbin', Edwin Waugh, Ben Brierley and Samuel Laycock. Richard Rawcliffe wrote a poem in memory of Eliza Cook, and George Hull wrote one to Adelaide Anne Procter. Chains of dedicatory poems hitched the wagons of obscure rhymers to poetic stars: Burns was celebrated by the Chartist poet Gerald Massey; Massey by Billington, and Billington by another Blackburn poet, George Hull. ${ }^{35}$ When, in 1886, Abram commissioned John T (Jack) Baron to write his weekly 'Rhyme in the Dialect' for the Blackburn Times, he offered payment in kind with a set of books by the great poets.
"Jack" apologised for looking a gift horse in the mouth, but begged to be informed of the poets to be represented, and Mr Abram went through a long list, only to be told that the young contributor already owned every one of them, and very many more, in fact, so much good literature that Mr Abram promptly suggested other arrangements, which were as promptly accepted $\ldots{ }^{36}$

Billington was notorious for employing his knowledge in accusations of plagiarism against his 'brother bards'. Typical is a spat between him and John T Baron, played out in the Blackburn

\footnotetext{
${ }^{33}$ Hull, Poets and Poetry, 245.

${ }^{34}$ Watson, 'William Billington: Cotton Operative, Teacher and Poet', 79.

${ }^{35}$ Maidment, Poorhouse Fugitives, 162.

36 ‘1,000 not out: A pen-sketch of Jack o’ Ann’s’, Blackburn Times, 13 January 1906.
} 
Standard in 1880. Billington had a poem, 'Spring', published in the Blackburn Times (29 May); next week, in the Standard, a certain 'Quizzical' accused Billington of lifting lines from Milton's 'Paradise Lost', and claimed that another local poet, John Walsh, had plagiarised Billington. That began a string of letters and poems, full of claims and counter-claims of plagiarism, including one suggesting that perhaps it was 'some Mr Milton' who had borrowed from Billington, and that this Mr Milton's address should be published.$^{37}$ Each letter and poem displayed a deep knowledge of local and canonical poets.

\section{Associational culture}

Blackburn's poets could learn from their elders, debate their craft, receive comments on their efforts and take their first steps as performers of poetry, in the town's many literary and debating clubs and societies, mutual improvement classes, celebratory dinners marking the birthdays of Burns, Shakespeare and other famous names, and the handful of pubs where poets and other writers gathered. Billington and Abram were founder members of the Blackburn Literary Club, but there was also a Burns club, a Bohemian Club and an Athenian club; some had their own premises, while others met in pubs or meeting rooms. There were also ad hoc gatherings to celebrate the anniversaries of Burns and Shakespeare, as we have seen. Membership included working-class and middle-class men. Friendly societies, churches and Sunday schools also offered similar opportunities in less concentrated form, with some churches, such as Montague St Congregational Chapel, running prize poetry competitions. In 1879 John T Baron won 11 volumes of Tennyson's works in this chapel's May Day contest. ${ }^{38}$

There were times and places for poetry to be performed and discussed. Verse by Billington and John Baron was set to music by George Barton, a Blackburn Standard employee and choirmaster at St James' church. ${ }^{39}$ A hymn composed by Prince was sung by thousands of Sunday School children at

\footnotetext{
37 'Piracy', 5 June; 'The Charge of Piracy', 12 June; 'Piracy', 19 June; 'Plagiarism', 26 June, all Blackburn Standard, 1880.

${ }^{38}$ Hull, Poets and Poetry, 366.

${ }^{39}$ Hull, Poets and Poetry.
} 
the laying of the foundation stone for Blackburn Infirmary on 24 May 1858. In 1887 George Hull wrote a poem celebrating the jubilee of the Catholic Brethren friendly society, which was read on the occasion by James Hull. ${ }^{40}$ Blackburn's poets had their regular haunts. There was the Black Horse on Northgate, 'the rendezvous of lawyers, auctioneers, agents, reporters, local poets, and literatteurs', run by Will Durham, known as 'the Blackburn chronologist'. Journalist and poet William Whittaker recalled a visit with another reporter in the 1850s or 1860s, where they found John Boothman of the Blackburn Weekly Times and 'on the other side sat the burly bard of Ribblesdale, Dugdale, and two other poets -- Billington and Baron, and snoring in the chimney corner sat John C Prince ...' Mr Gregory Walker, landlord of the Spread Eagle Hotel in Cable St, hosted 'conversaziones' every Sunday evening, in a large room specially fitted out for these discussions, and inaugurated by Billington, who gave lectures there and joined in the debates. Other pubs followed suit. ${ }^{41}$ Billington became a pub landlord himself, at the Nag's Head on Northgate and then the 'Poet's Corner' on Nab Lane. ${ }^{42}$ William Whittaker recalled a daytime visit to Poet's Corner. Single sheets of Billington's dialect songs hung in the window, for sale at a penny each. Inside, there were portraits of Billington and Prince on the walls.

There is nobody in the front room to the right, so we turn into one to the left. This apartment is appointed to various capacities of most heterogeneous character. It is at once the kitchen, tap-room, study, and gymnasium, and the table, of about four feet square, answers the threefold purpose of dining-table, ale-bench, and writing-desk. The poet is sat in an arm-chair, occupying a convenient position on the ingle side of it. That portion of the table is consecrated to the muse, and when we enter we find it littered with scraps of manuscript. He is not cultivating poesy just now, but peeling potatoes ... ${ }^{43}$

On Wednesday evenings Billington offered free grammar, composition and elocution classes, and aspiring poets would take their poems to him at Poet's Corner for his criticism and suggestions.

\footnotetext{
${ }^{40}$ Blackburn Times 3 Sept 1887.

${ }^{41}$ [W. Whitaker], 'Personal Reminiscences of the Poet Billington' VII, Blackburn Times, 15 October 1887.

${ }^{42}$ [Whitaker], 'Personal Reminiscences' VIII, Blackburn Times 22 October 1887.

${ }^{43}$ [Whitaker], 'Personal Reminiscences' X, Blackburn Times 5 November 1887.
} 
Billington's nephew John hosted elocution classes and debates at the Regent Hotel, and many clubs and societies had their own meeting rooms.

\section{Pride in local culture}

There is no sense of inferiority, of provincial culture as second-rate, or of being peripheral to any desirable centre, in the poetry, criticism, memoirs and other writing connected to Blackburn's poetic culture. In fact, quite the opposite - they were proud of their class and of their town. This might have surprised Matthew Arnold (who believed that provinciality was caused by 'remoteness from a centre of correct information [and] want of a centre of correct taste'), and perhaps to some modern scholars. ${ }^{44}$ Poems in tribute to Burns and Sir Walter Scott and literary celebrations of Burns's birthday suggest that these Scottish writers' pride in their culture, including the Lowland Scots language, influenced many Blackburn poets (Burns's democratic convictions may also have appealed). The language of Burns helped to legitimise Lancashire dialect, from the late 1850s onwards (Manchester's Sun Inn group had not taken dialect seriously in the 1840s). ${ }^{45}$ Dialect had extraordinary power to express a feeling of community. ${ }^{46}$

Local pride is manifest in the introduction to Hull's anthology, which presents Blackburn's poets as a major part of the town's history, and poetry as Blackburn's pre-eminent art-form. This idea is captured in a review of two local poetry volumes in 1888 :

Notwithstanding our unsavoury reputation; and notwithstanding the smoke in which we are enveloped, Blackburn is a town, which, in a literary sense, has no need to be ashamed. The "sacred nine" [the nine muses of Greek legend] favour it. On its hill sides

\footnotetext{
${ }^{44}$ M. Arnold, 'The Literary Influence of Academies', in Essays in Criticism (London, 1865), 60.

${ }^{45}$ Vicinus, 'Literary Voices', 76.

${ }^{46}$ B. Hollingworth, Songs of the People: Lancashire Dialect Poetry of the Industrial Revolution (Manchester, 1977), 6; Brian E. Maidment, The Poorhouse Fugitives: Self Taught Poets and Poetry in Victorian Britain (Manchester: Carcanet, 1992), ch. 6, 'The defence of the dialect'.
} 
and by its streams poets wake their lyres, and if the critics remind us that the muse is doric in its form, may we not plead that it is Attic in its conceptions and in its spirit. ${ }^{47}$ As in other towns, Blackburn's poets wrote scores of poems to each other, strengthening their poetic community and creating a local canon. Manchester poet Angus Wilson had mentioned 28 local poets and hangers-on in 'The Poet's Corner', his celebration of the Sun Inn group, and Blackburn's Billington, possibly inspired by the Manchester poem, listed 26 names in his elegiac 'Where are the Blackburn poets gone? ${ }^{48}$ In the same volume, he dedicated poems to John Critchley Prince and George Salisbury, while his earlier volume, Sheen and Shade (1861) included another to Salisbury and one to John Baron. George Salisbury wrote an acrostic poem in praise of Billington as 'bard of Blackburn'; in contrast, John Baron was probably the 'JB' who signed an obscene single sheet poem about Billington, probably written in the early 1870 s after his second wife left him. ${ }^{49}$ Entitled 'A poet's last legacy, or a burlesque on a scurrilous friend', its 26 stanzas are an odd mixture of respect for Billington's poetry, and mockery at his womanising and his wife's unfaithfulness. The poem is a reminder that community does not require harmony. Scores of more respectful poems were written about Billington when he died, by, among others, George Hull, John Rushton, James Jardine ('Lines Written on Reading the Account of the Death of the Poet, William Billington, in the "Blackburn Times"') and John Walker (the last stanza of Walker's elegy was inscribed on Billington's gravestone). ${ }^{50}$ Some poets attracted more tributes than others: Dugdale was celebrated in poems from Billington (performed on Dugdale's $77^{\text {th }}$ birthday, and quoting many of Dugdale's lines), from John Baron, from Prince, two from John Charlton and several from Robert Clemesha; Prince was honoured in poems by Billington, Hull, John Baron and John Charlton among others, and John T. Baron was congratulated by brother bards at each milestone on his way to contributing a dialect poem

\footnotetext{
47 'Literary Blackburn and a Letter from Edwin Waugh', Blackburn Standard 28 April, 1888. The 'Doric' dialect of ancient Greece was associated with the peasants of the countryside whilst the 'Attic' dialect was spoken in the more sophisticated city states.

${ }^{48}$ Maidment, Poorhouse Fugitives, 163-166; W. Billington, Lancashire Songs, with Other Poems and Sketches (Blackburn, 1883), 125-126.

${ }^{49}$ Thanks to David Hughes for identifying this poem, held at BCL; Watson, 'William Billington: Cotton Operative, Teacher and Poet', 82.
}

${ }^{50}$ Abram, Blackburn Characters, 232; Hull, Poets and Poetry. 
every week to the Blackburn Times for more than 30 years. The Hull anthology is full of such dedicatory poems. When Blackburn poets wrote poems about other Blackburn poets they were inventing a tradition, giving the town's literary history a continuity and a history, building a 'community created by the act of writing poetry' -- and by reading it. ${ }^{51}$ Response poems -exchanges of compliments or insults - built this sense of community, creating networks and relationships.

A tradition of commemoration brought together many element of Blackburn's poetic culture, as seen in a 'complimentary dinner' given after Billington's death by his nephew John in the 'vocal and elocutionary rooms' of his Regent Hotel. His uncle's poems were recited, including 'Where are the Blackburn poets gone?', alongside songs, other recitations, and a toast to 'the Blackburn Bards, past and present', proposed by Mr J.D. Hirst

who, in an able and finished manner, ran through the list of Blackburn writers during the past thirty years, mentioning and slightly criticizing the writings of Dugdale, Baron, Prince, Rawcliffe, Abram, Chadburn, Yates, JT Baron (“Jack-o’-Ann's”), William Baron ("Bill-o-Jack's"), Chippendale ("Chip"), Ince, and a few others, last but not least being William Billington ... the evening's entertainment ... for variety of selections and ability in rendering, has seldom been equalled by a gathering of working men, all Blackburnians. $^{52}$

The newspaper report of this event reveals a canon of local poets, a depth of knowledge of their work, and a pride in humble, local origins.

\section{The vital role of the local press}

Local newspapers were probably the most common type of publication in which poetry was encountered in the Victorian era. I estimate that something in the order of four million poems were

\footnotetext{
${ }^{51}$ Maidment, Poorhouse Fugitives, 162; see also W.J. Christmas, 'The Verse Epistle and LaboringClass Literary Sociability from Duck to Burns', in Goodridge and Keegan, 39-40 for Romantic-era labouring-class poets.

${ }^{52}$ Blackburn Standard, 14 January 1888, p.8.
} 
published in local newspapers during Victoria's reign in England alone, far more than were published in books. Between a third and a half of these poems were original and locally produced (with the remainder reprinted from elsewhere) ${ }^{53}$ Local newspapers published poetry more frequently than London dailies, and they outsold London newspapers and periodicals in aggregate from the late 1850s onwards, making them the most widely read type of newspaper for the last four decades of Victoria's reign. Provincial papers typically published one poem per issue at mid-century, rising to two per issue from 1860 onwards.

Blackburn's newspapers, like those of many other towns and cities, had a long tradition of publishing poetry, from the town's first newspaper, the Whig Blackburn Mail (est. 1793) onwards. The Mail became the Gazette in 1829, closing in 1843. The Tory Blackburn Standard launched in 1835, edited from London (not an unusual arrangement) by the poet and journalist Alaric Watts, published poetry regularly throughout its existence. ${ }^{54}$ Surprisingly, the Blackburn Standard published fewer poems than papers in many other towns, an average of one per issue, compared to more than three per issue in the Manchester Times. The town's Liberals regained their voice when the Blackburn Weekly Times launched in 1855, its first issue (2 June) including a half-column review of Longfellow's Voices of the Night and an 'original' anonymous poem. The paper flourished under the ownership of Ernest King from 1861 to 1867 , featuring some local poetry, but not every week. It became a significant local publishing platform when Abram became editor in 1867, employed by new proprietors George and James Toulmin, the most powerful newspapermen in north Lancashire, who also owned the Preston Guardian. While Blair argues that Liberal newspapers were more open to working-class poets, seeing cultural achievement as a sign that the lower classes deserved the vote, Blackburn's Tory papers were equally welcoming. ${ }^{55}$

\footnotetext{
${ }^{53}$ A. Hobbs and C. Januszewski, 'How Local Newspapers Came to Dominate Victorian Poetry Publishing', Victorian Poetry 52:2 (2014), 65-87.

${ }^{54}$ Morning Post, 7 December 1835, 'Court of King's Bench: Alaric A Watts v. Fraser and Moyes'.

${ }^{55}$ Blair, 'Newspaper Press', 272.
} 
Poetry about local people, places and events was used by newspapers to fuel and exploit local patriotism, one of many such techniques through which the local press benefited from local identity. ${ }^{56}$ An obituary for Billington captured the sense of literary magic and prestige that poetry could impart to ordinary places:

he had felt the fresh breeze of Parnassus, the Muses had anointed his eyes until the grimy streets of Blackburn, the moorlands that hedge us in, and the people that move to and fro among our thoroughfares and mills became the themes of rhapsody and verse. ${ }^{57}$

'Local newspapers did not simply support existing working-class poets. They created them by providing an aspirational venue for publishing their works,' Maidment argues. ${ }^{58}$ Newspapers could even turn local poets into celebrities. Figure 3 shows a poster advertising the Blackburn Times, promoting one of its most popular attractions, the weekly dialect poems of John T Baron.

\footnotetext{
${ }^{56}$ A. Hobbs, A Fleet Street in Every Town: The Provincial Press in England, 1855-1900 (Cambridge, 2018), 279.

${ }^{57}$ Blackburn Standard, 12 January 1884, 2.

${ }^{58}$ Maidment, Poorhouse Fugitives, 272.
} 


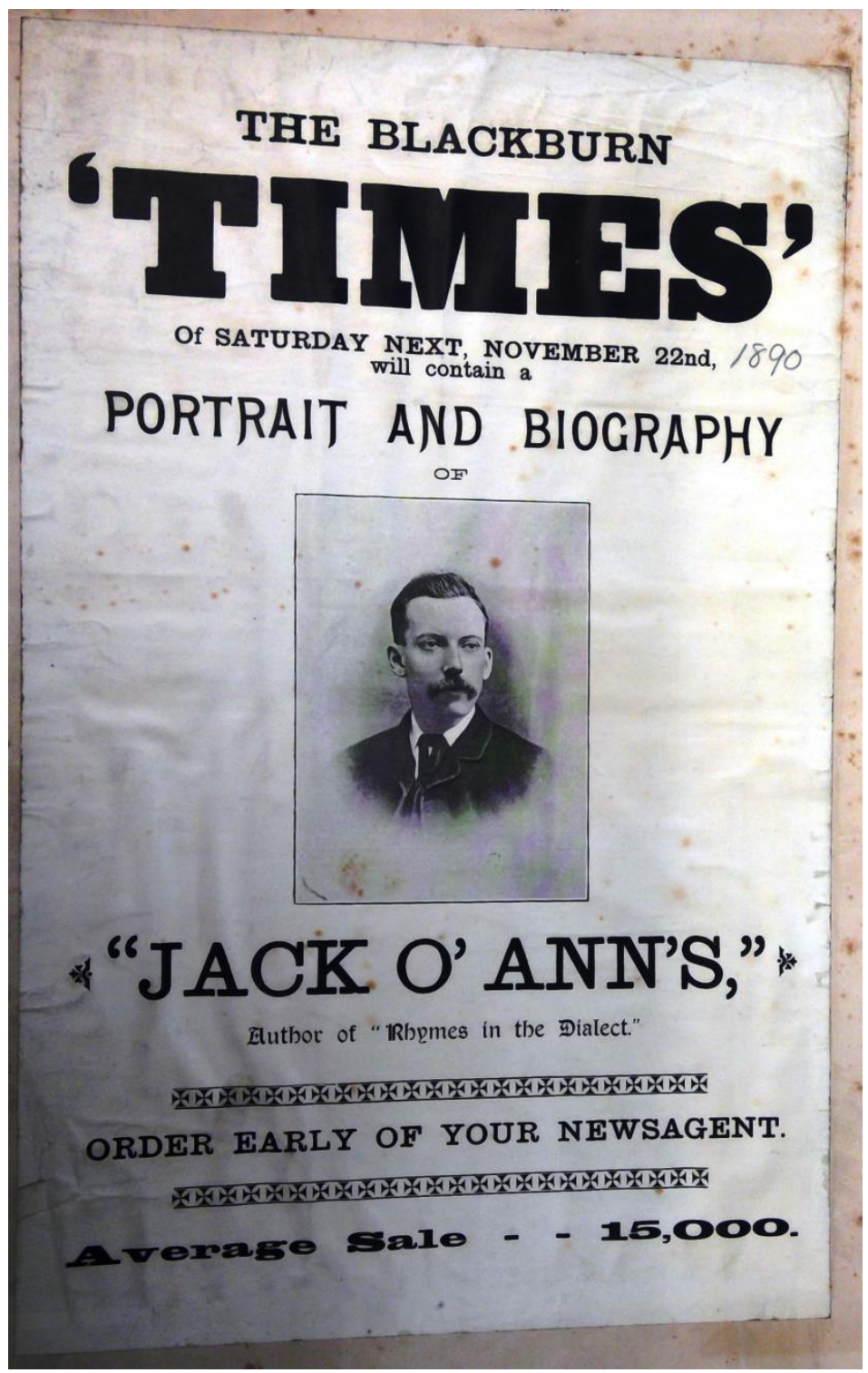

Figure 3. Advertising poster for Blackburn Times, 1890, featuring poet John T Baron (from John T Baron cuttings scrapbook, Blackburn Central Library).

Local newspaper editors were important patrons of working-class poets. They could enable publication, introduce the writer to other poets, use their contacts to ensure publication in other newspapers and possibly even London magazines, and assist those rare poets able to publish in volume form. ${ }^{59}$ Socialist writer and poet Ethel Carnie dedicated two of her books to W.H. Burnett, editor of the Tory Blackburn Standard \& Express. In the preface of Rhymes from the Factory she wrote: 'I am greatly indebted to the Editors of the two Blackburn weekly papers for having printed some of my earlier pieces. They brought me into notice when I had scarcely concluded myself

${ }^{59}$ Blair, 'Newspaper Press', 268. 
whether my verses were worthy of print. ${ }^{60}$ Newspapers were probably even more important for women poets than for men, who could meet more easily in pubs, clubs and societies. ${ }^{61}$ In $1840 \mathrm{~s}$ Manchester, Isabella Varley had to hide behind a curtain at the Sun Inn to hear one of her own poems being read. ${ }^{62}$ In Dundee, women contributors to the People's Journal were not invited to the newspaper's Christmas celebration. ${ }^{63}$

The Blackburn papers were unusual (but not unique) in their encouragement of poets from the labouring classes - but they had standards to maintain. Abram was remembered for his 'seeming cruelty', 'relentlessly consigning to the waste-paper basket the effusions of ... "Spring Poets"', ${ }^{64}$ However, brush-maker George Thomas Collins described a more encouraging side of Abram:

I came to Lancashire in 1868 , and although I had written, in my childhood and youth, some rhymes that I did not consider fit for print, I don't suppose I should have ventured to publish any had my esteemed friend, Mr. J. T. Baron, not persuaded me to send one piece to the "Blackburn Times" for publication. It was entitled "Memory and Hope," and was accepted; as several others were afterwards. I consider it a praiseworthy feature of Blackburn journalism that it encourages and fosters local talent, especially among the workers in this very busy hive of industry. Since then I have had a great number of pieces published in other journals..$^{65}$

Other studies of eighteenth-century Norwich, nineteenth-century Dundee and twentieth-century Gold Coast (colonial era Ghana), have all found the local press was central to local literary cultures. ${ }^{66}$

\footnotetext{
${ }^{60}$ E. Carnie, Rhymes from the Factory, by a Factory Girl (Blackburn, 1907), viii.

${ }^{61}$ F. Boos, Working-Class Women Poets in Victorian Britain: An Anthology (Peterborough, Ont., 2008), 15.

${ }^{62}$ M. Vicinus, The Industrial Muse: a Study of Nineteenth Century British Working-class Literature (London, 1974), 160.

${ }^{63}$ K. Blair (ed.), Poets of the People's Journal: Newspaper Poetry in Victorian Scotland (Glasgow, 2016), xxv.

${ }^{64}$ Hull, Poets and Poetry, 172.

${ }^{65}$ Hull, Poets and Poetry, 264-65.

${ }^{66}$ Chandler, 'Athens of England'; Blair, “"A Very Poetical Town”; S. Newell, 'Entering the Territory of Elites: Literary Activity in Colonial Ghana', in K. Barber (ed.), Africa's Hidden Histories:

Everyday Literacy and Making the Self, (Bloomington, 2006), 211-235.
} 
Most of the verse in the 'poet's corner' of Blackburn's newspapers earned no money for the poets. However, there were other ways in which poetry paid, chiefly through writing advertising verse (in the same way that $20^{\text {th }}$-century writers such as F Scott Fitzgerald, Dorothy Sayers and Salman Rushdie earned their living from writing advertising copy). No doubt some advertisers wrote their verse themselves, while others paid a recognised poet to do it, ensuring high-quality verse, as in the apocryphal boast of Mrs Warren, when asked about the success of Warren's boot blacking (famous in the 1820 s for its rhyming newspaper advertisements): 'We keeps a poet' (rumoured to be Lord Byron). However, for the poet it was a different matter; it was a shameful thing to prostitute one's talent in such a way. ${ }^{67}$ John Critchley Prince was 'compelled to degrade his genius by writing rhyming advertisements for a tailor!' his biographer wrote in horror. Prince wrote verse for a Mr Killorn (which he rhymed with 'adorn') of Ashton-under-Lyne, in adverts for the Ashton Reporter, from 1858 to 1860 . A note from Prince to Killorn survives: 'Can I write anything more for you? Remit me seven shillings, and I will send you another good one. ${ }^{68}$

There was paid work for local poets at election times, writing political squibs in support of one or other party, or sometimes both. Abram engineered the exposure of one pen for hire, John Baron, during the 1868 election:

Like the rest of the Blackburn "School" of Poets, almost without exception, "Jack" Baron, when party politics were rife, yoked his Pegasus to that car, and wrote election rhymes - squibs, satires, and panegyrics - charged with violent expletives ... ${ }^{69}$

Baron was a Tory, writing two or three pieces for the Standard and the Patriot each week, while most poets - Billington, John Walker, Richard Rawcliffe, H.G. Graham, Henry Yates and others - were Liberal supporters, being paid by the candidates to write verses for the Liberal Times. Baron, believing that the Liberals paid more than the Tories, submitted an anti-Tory rhyme to the Times with

\footnotetext{
${ }^{67}$ K. Blair, 'Advertising Poetry, the Working-Class Poet and the Victorian Newspaper Press', Journal of Victorian Culture 23:1 (2018), 103, 106.

${ }^{68}$ D. Lithgow, The Life of John Critchley Prince (Manchester, 1880), 251-53.

${ }^{69}$ Abram, Blackburn Characters, 334-335.
} 
accompanying pseudonym, but Abram 'accidentally' printed his real name beneath the poem. Baron was furious.

Newspapers rarely paid for poetry (rhyming ads and election squibs were paid for by advertisers and political parties respectively). When they did pay, it was more from charity than necessity, and only to well-known poets. John Critchley Prince appears to have been paid a regular sum by the Preston Guardian from 1853, whilst living in Blackburn, judging by the quantity of his poetry published there. The arrangement probably began after he wrote to the editor:

I shall be happy to contribute now and then to your paper; and if you could afford to pay me two or three shillings a week, I will engage to supply you with lyrics (weekly), on moral, elevating, and cheerful subjects. They shall be written expressly for your journal... Can you set me a literary task? I will do the best I can. ${ }^{70}$

When Billington was short of money, the Blackburn Standard commissioned a series of 'Samlesbury Tales and Legends'. ${ }^{71}$ Prose such as this seems to have been paid for more often than poetry. Joseph Baron was paid $£ 112 \mathrm{~s} 6 \mathrm{~d}$ for a commissioned dialect series, 'Brimstooan and Traycle' by the Preston Herald in $1893 .{ }^{72}$ John T Baron was paid for his Blackburn Times series of 'Rhymes in the Dialect'. Poets were occasionally paid for particularly popular poems, as with Edwin Waugh, who received a guinea from the Manchester Examiner \& Times for his 1856 'Come whoam to the childer an' me'. ${ }^{73}$ But generally the economy of local newspaper poetry was one of over-supply, depressing the market. Local newspapers dominated Victorian poetry publishing, but there were other outlets. Poetry was occasionally published in slim volumes, in regional and even national magazines, more often as penny sheets. Poets could earn a few pennies - very occasionally a few pounds - from printing and selling single poems, known as broadsides, either bearing the cost themselves, or persuading a printer to take

\footnotetext{
${ }^{70}$ Lithgow, Life of John Critchley Prince, 225-226.

71 “"The Blackburn Weeklies” -- Which Is the Best General Newspaper?', Blackburn Standard, 18 August 1888.

72 'Action against a Preston newspaper proprietor', Preston Chronicle, 12 August, 1893, 4.

${ }^{73}$ Manchester Libraries, Information and Archives, GB127.MS f 828.89 W15, certificate of copyright of 'Come whoam to thi childer an' me', and notes on its publication, 1856, in scrapbook compiled by Edwin Waugh. I am grateful to Brian Hollingworth for this reference.
} 
the risk. ${ }^{74}$ Blackburn's Joseph Hodgson paid for his poems to be printed himself; Billington's

'Th'Surat Weyver' was first published as a broadsheet, selling 14,000 copies; he sold a longer work, 'Pendle Hill' (1876) as a 3d pamphlet (on the back cover is written 'Copies of this poem may be had from the author, Poet's corner, Nabb Lane, Blackburn'). John T Baron published his 'Charge of the Light Brigade' as a broadsheet (although one critic claimed that it 'hung up for sale in the stationers' windows till the paper went brown and black with age and fly dirt') ${ }^{75}$ In contrast, John Walker's poem 'My Grandad' was published by John Heywood in his series of penny 'Lancashire Songs'. ${ }^{76}$ Besides Hull's book, the bards of Blackburn were anthologised in at least two series of contemporary newspaper articles, and commemorated in further series in the $20^{\text {th }}$ century. George Salisbury wrote the first newspaper anthology, in the Preston Herald, beginning in May 1862, and Billington's series 'Recollections of Local Celebrities' in the Blackburn Standard in 1883, written under the pseudonym 'Jonathan', included many poets and their poetry.

\section{Bardic values}

Brian Maidment has shown how the term 'bard' was more than an honorific in working-class literary cultures such as Blackburn's. Romantic poets, especially Wordsworth and Shelley, had taken the idea of the Welsh bard, and made it prestigious and attractive to provincial self-educated writers who were excluded geographically and culturally from the centres of literary power; Blackburn poets used the idea in a less elitist way, and these 'modest poets' were given a bardic status because they were 'slightly more articulate than their neighbours'. This was 'poetry written by artisans for artisans', who valued poetry and poets in particular ways. ${ }^{77}$ They believed that 'poetry had a social function in binding a community together through expressing the simplest commonly held values' and that therefore the poet had a duty to the community, which was acknowledged by

\footnotetext{
${ }^{74}$ Vicinus, 'Literary Voices ', 742.

75 'Plagiarism', Letters, Blackburn Standard, 26 June 1880.

${ }^{76}$ Hull, Poets and Poetry, 280.

${ }^{77}$ Maidment, Poorhouse Fugitives, 210, 209.
} 
giving the poet a public status. ${ }^{78}$ This communal function can be seen in the many allusions to local places, characters and events, to the working-class home and social institutions, and to working life in the cotton mills.

Many Blackburn residents seemed to take the poetry of their neighbours to heart. This can be seen in a series of Sunday-night debates on the local press at the Regent Hotel which ran for three weeks in August 1888, and in which poetry featured prominently. Mr Shepherd Hindle, a supporter of the Blackburn Times, singled out that paper's 'literary content', developed under the editorship of William Abram. However, Mr John Pickup (an occasional poet himself) believed that Abram's departure to the rival Weekly Express had damaged the Times: 'since Mr Abram has gone to the enemy, and Mr Walker [a journalist poet] to Warrington, the selection for the "Poets' corner" in the Times is in very queer hands indeed'. The Standard now had better dialect poems, he believed. ${ }^{79}$ One speaker in the following week's debate agreed that the Times had lost its pre-eminent place as a 'literary paper' since Abram's departure, but in the third week's debate an unnamed poet defended the Times:

one of Blackburn's "Royal Bards" ... came forward with an overburdened portfolio of "Facts, figures and fallacies" in the endeavour to show that the Blackburn Times was first on the list of local weeklies.

A poetic Mr Shorrock also backed the Times, 'and stumbling in his arguments, brought down the house by bursting into a spontaneous fit of comical rhyme'. ${ }^{80}$

The Express was mocked for the 'Mary Richardson' poetry hoax played on Abram, but a Mr Walton was defiant in defence of the Express: 'we haven't much poetry, and we don't want any. (A Voice: "Not after Mary Richardson." Loud laughter, in which the speaker joined....) ${ }^{\prime 81}$ The Standard, the oldest of the three papers, was praised by Mr Pickup for its 'smooth and euphonious dialectic rhymes

\footnotetext{
${ }^{78}$ Maidment, 324.

79 'The Blackburn Weeklies: Which is the best general newspaper?' Blackburn Standard, 18 August 1888.

80 'The recent debate on the Blackburn weeklies', Blackburn Standard 25 August 1888; 'Which is the best Blackburn Weekly?' Blackburn Standard 1 September 1888.

${ }^{81}$ Blackburn Standard 25 and 18 August 1888.
} 
entitled "Bits i' Broad Lanky"', but Mr Hindle mocked its resident poet, 'a gentleman called ----, who scribbles a bit of doggerel rhyme, but who never had or has a grain of poetry in his soul. And yet the Standard was the paper to laud him as the Laureate of Blackburn.' These debates show a depth of knowledge of local poets beyond their immediate circle, their close links to newspapers, and the teasing and robust criticism suggestive of genuine community.

Many readers memorised poetry by Blackburn writers, or quoted it in print and from the platform and the pulpit. History lecturer James Bowker ('of London, late of Preston') finished his lecture to unemployed Preston workers in 1863 'in the words of W. Billington, the weaver-poet of Blackburn, [and] bade them trust in the future and hope for better times. ${ }^{82}$ The journalist John Walker was able to quote a verse from a Billington poem written 25 years before, from memory. ${ }^{83}$ The localness of much of the poetry comforted 'Blackburnians' far from home: James Lonsdale wrote from South Africa in 1889 to say how much he enjoyed the Blackburn Express \& Standard, including 'the really good poetry and prose in our dear old dialect, by “Tum o'Dick o' Bob's.” Billington is dead, but you have found a worthy successor ..., ${ }^{84}$

As local laureates, poets were expected to write verse celebrating local and national occasions, such as the opening of the free library or the infirmary. John T Baron's duty to provide a dialect poem for the Blackburn Times every week was recognised by his employers, Henry Livesey Ltd, who gave him time off from his job as a turner and fitter at the Greenbank Foundry for his poetry, rather like time off for the civic role of jury duty. ${ }^{85}$ In return, Blackburn's poets were honoured and remembered. In the 1850s 'the Scotchmen of Blackburn gave a banquet to the "Bards of Blackburn"'; they were given titles, such as the 'bard of Ribblesdale' for Dugdale, with others linked to the part of town where they lived -- the 'bard of Grimshaw Park' for John Baron, 'bard of Kirk Lane’ for Joseph Hodgson and 'bard of Islington' for Henry Yates. The response from both public and other poets to the death of Billington shows the value placed on local bards. An appeal was launched for funds towards a

\footnotetext{
${ }^{82}$ Preston Herald 21 February 1863, p.10.

${ }^{83}$ [Whitaker], 'Personal Reminiscences V', Blackburn Times, 1 October 1887.

${ }^{84}$ Blackburn Standard \& Weekly Express, 22 June 1889, 6.

85 '1,000 not out!', Blackburn Times, 13 January 1905.
} 
memorial for the poet; contributors included Blackburn Literary Club (£7, 3s), many local litterateurs, publishers of the two Blackburn weeklies (10/6 each) and the Dog and Otter Arms Friendly

Discussion Club (8/1), among many others. The money paid for an ornate gravestone and a portrait which hung in the hall of the Free Library. ${ }^{86}$

In working-class Blackburn, poetry was ordinary, ubiquitous even. Poetry was used to collect debts (as in 'A Dunning Letter to a Brother Bard', by grocer Robert Clemesha), to mock and insult, to campaign, or to advertise ${ }^{87}$ As with singing or conversation, everyone had the right to rhyme, whilst it was recognised that some could elevate this everyday human activity into art. As in Wales, the source of the Bardic tradition, Blackburn poets were 'normal', and poetry was 'not so much a mystery as a craft, the techniques of which can be learned from others in the community ${ }^{88}$ Maidment believes that working-class espousal of the Romantic idea of the bard encouraged the idea that 'all individuals possessed the sensibility, if not the skill or linguistic resources, to be poets.' Some of the poetry published - and unpublished -- in the local press suggests that many people believed lack of skill was no barrier, that everyone had the right to express themselves in verse, to indulge in what Laporte calls 'poetic behaviour'. ${ }^{89}$ The cultural politics of the Chartist movement may also have been an influence. As Mike Sanders has established, the belief that working-class people could create and appreciate poetry, one of the highest arts, was seen as evidence that they also deserved the vote. ${ }^{90}$

But was the poetry of working-class Blackburn any good? The quantity was more significant than the quality of the verse, I would argue. Kirsty Blair acknowledges that aesthetic quality is not the main reason for studying working-class newspaper poetry, which usually came under the classification of

\footnotetext{
${ }^{86}$ Blackburn Standard, 25 September 1886,1; Hull, Poets and Poetry, 231.

${ }^{87}$ For Clemesha poem see Hull, Poets and Poetry.

${ }^{88}$ Goodridge, 'Informal Notes on Groupings, Circles and Categories'; M.A. Constantine, “"British Bards": The Concept of Laboring-Class Poetry in Eighteenth-Century Wales', in Goodridge and Keegan, 108.

${ }^{89}$ B.E. Maidment, 'Class and Cultural Production in the Industrial City: Poetry in Victorian Manchester', in A.J. Kidd and K. Roberts (eds) City, Class and Culture: Studies of Cultural Production and Social Policy in Victorian Manchester (Manchester, 1985), 153;Charles LaPorte, 'Post-Romantic Ideologies and Victorian Poetic Practice, or, the Future of Criticism at the Present Time', Victorian Poetry 41:4 (2003), 521.

${ }^{90}$ M. Sanders, The Poetry of Chartism: Aesthetics, Politics, History (Cambridge, 2012), 64.
} 
lyric poetry, and covered stock subjects: the countryside, romance or elegy, 'written in easily recognisable verse forms with predictable patterns of rhyme and meter. ${ }^{.91}$ Blair and other literary scholars believe that working-class poets did not place much value on originality in form and content, distinguishing them from 'high' Romantic bards such as Shelley and Wordsworth. What seems clichéd, unoriginal and formulaic to our eyes was a way of showing that the writers were steeped in the poetic tradition, and expressed the communal nature of working-class culture; it was also what newspaper editors wanted. ${ }^{92}$ Indeed a search of the digitised George Hull critical anthology of Blackburn poets finds only one use of the word 'originality' applied to poetry (that of John Baron), confirming that this was not an important criterion. Perhaps, too, the reams of sentimental, consolatory dialect poetry came from the same impetus as the temperance and co-operative movements, defending and celebrating family and community as institutions necessary for survival. And while poets did not need to be literate, most of Blackburn's working-class writers were proficient in both standard English and Lancashire dialect (indeed the complex process of rendering dialect phonetically so that it could be understood, required a high level of literary skill). ${ }^{93}$ The fact that these readers treasured and used such poetry, in ways we tend to reserve for only the 'best' poetry, challenges our judgments of poetic quality and the limitations of 'bad art'. An obituary of Billington claimed that

there are those amongst the rank and file of our Blackburn population to whom the homely rhymes of a Billington are more congenial and more dear than the stately and sustained splendours of a Byron, a Tennyson, or a Scott. ${ }^{94}$

\section{Conclusion}

\footnotetext{
${ }^{91}$ Blair, 'Newspaper Press', 265, 271.

${ }^{92}$ Blair, Poets of the People's Journal, xix-xx; Blair, “"A Very Poetical Town”, 99; Sanders, Poetry of Chartism, 50.

${ }^{93}$ Ashton-under-Lyne poet John Stafford could neither read nor write, but published a book of verse, Songs, Comic and Sentimental (Ashton, 1840): R. Hall, 'At the Dawn of the Information Age: Reading and the Working Classes in Ashton-under-Lyne, 1830-1850', in J.J. Connolly et al (eds), Print Culture Histories Beyond the Metropolis (Toronto, 2016), 260.

${ }^{94}$ Blackburn Standard 12 January 1884, 2.
} 
Two individuals made Blackburn's proletarian literary culture extraordinary, a working-class poet who inspired, mentored and brought others together, and a middle-class editor who believed in education and culture for all. But the town's vibrant local press was part of the infrastructure which made this possible, providing an outlet and a loyal following, boosting the status of poets through encouragement and criticism, helping them to build a community, and preserving their memory after death.

Brian Maidment provocatively suggests that a local working-class poetry culture such as Blackburn's was a failure, because it had little significance beyond the town, and did not enable writers to make a living from their poetry. ${ }^{95}$ Few Blackburn writers published in venues other than the local press (exceptions included Yates in Ben Brierley's Journal and Casssell's Saturday Journal, John T Baron in Young Folks, Rambler and Momus, and Joseph Baron's plays performed in London theatres). And while Prince and occasionally Billington appear in some scholarly works and anthologies today, and a handful of others have been included in Lancashire anthologies, no Blackburn poets are admitted to the small canon of Victorian poets. In their day, most working-class poets from Blackburn or anywhere else were excluded from high Victorian culture because they were denied educational and publishing opportunities by an elite who looked down on them.

But these may be the wrong standards by which to judge a local working-class literary culture. Many of Blackburn's poets may have dreamed of being mentioned in the same breath as Wordsworth, Tennyson or Longfellow, but they also valued the power of poetry to change lives, to console and to speak on behalf of a community. On these terms the bards of Blackburn were hugely successful, infusing their town with poetry in a way which has rarely been equalled. Working-class culture, aided by middle-class local newspaper editors, created 'a milieu that encouraged working men and women to participate in and help to shape a topical, politicised, satirical, and self-aware literary culture; one that genuinely offered pleasure, inspiration and a sense of self-worth to writers and readers who were excluded from other forms of cultural participation'. ${ }^{6}$ They

\footnotetext{
${ }^{95}$ Maidment, Poorhouse Fugitives, 210, 250, 324.

${ }^{96}$ Blair, Poets of the People's Journal, xxvi.
} 
may have been peripheral to culture as imagined by Arnold (although they revered the canon), but they were central to the culture of their town. As a single group, they were not as significant as coteries with greater economic and social advantages such as the Lakes poets or the Bloomsbury set. But when one places the bards of Blackburn alongside those of Manchester, Dundee and other places (all aided by a national network of local newspapers), the cultural map of Victorian Britain begins to change. Literary culture, and literary significance, was more decentralised, and therefore more genuinely national, than previously thought. 